\title{
CHILDREN'S COGNITIVE DEVELOPMENT AND VAK LEARNING STYLES: TEACHING STRATEGIES FOR YOUNG LEARNERS
}

\author{
Yeni Ikawati \\ yenibudiyanto@gmail.com \\ Semarang State University
}

\begin{abstract}
An effective English teacher plays significant roles to the success of students who learn English as their foreign language at classroom. First, it's crucial to know 'whom we teach' before we set plans with lots of instructional practices which put on high demands.

Getting to know who our students are, how their cognitive developments are, and in what ways they prefer to learn English are the best and basic starts to establish the following steps. Second, English teachers then have to able to consider and determine what strategies to use in order to make relevant input, purposeful and meaningful process, and yield significant and successful outcomes. In accordance with those two important things, this paper is aimed to (1) define who young learners are, (2) explore young learners' cognitive development, (3) define vak learning style, and (4) provide strategies to teach them. Teachers who teach young learners are hoped to be able to create relevant input by giving them meaningful process, and successfully outcomes.

Keywords: young learners, children's cognitive development, vak learning styles, teaching strategies
\end{abstract}

\section{INTRODUCTION}

The characteristics of young learners mentioned by Clark (1990) are: First, children are developing conceptually. They develop their way of thinking from the concrete to the abstract thing. Children have no real linguistics, different from the adult learners that already have certain purpose in learning language, for instances, to have a better job, children rarely have such needs in learning a foreign language. They learn subject what schools provide for them. Second, children are still developing. They are developing common skill such as turn talking and the use of body language. Third, young children are very egocentric. They tend to resolve around themselves. And forth, children get bored easily. Children have no choice to attend school. The lack of the choice means that class activities need to be fun interesting and exciting as possible by setting up the interesting activities.

While cognition is the mental activity and behavior that allows us to understand the world, it includes the functions of learning, perception, memory, and thinking; and it is influenced by biological, environmental, experimental, social, and motivational factors. Knowledge and understanding of children's cognition have to be built in teachers' mind in order to give them useful and meaningful intake during the process of their learning. And, it is surely yes, then, the children will get great outcomes.

In reality, in any classroom, teachers are faced with a number of different individuals with different learning styles and preferences. The term 'learning style' refers to two related ideas: 
firstly, students have different preferences for how learning material is presented, and secondly that when material is presented in a way that suits a learner's preference, learning is somehow enhanced. Harmer

(2007) stated that some students are especially influenced by visual stimuli and are therefore likely to remember things better if they see them. Some students, on the other hand, are especially affected by auditory input and, as a result, respond very well to things they hear. Kinesthetic activity is especially effective for other learners, who seem to learn best when they are involved in some kind of physical activity, such as moving around, or rearranging things with their hands.

From the descriptions above, generally, teachers in early childhood education must understand well whom they teach, how their cognitive developments are, and their diversity of learning styles in the process of receiving knowledge. As each age makes a huge difference among children, teachers have to be able select appropriate language focus and skills to teach young learners. And since child is likely to have a different learning style, students need a variety of lesson plans and activities to engage the entire class. Finally, significant outcomes and successful learning will be among teachers and students.

\section{WHO ARE YOUNG LEARNERS?}

According to Harmer (2007), within education, the term children are generally used for learners between the ages of about 2 to about 14. Students are generally described as young learners between the ages of about 5 to 9 , and very young learners are usually between 2 and 5 .

In the mean time, to Ersöz (2007), young learners are categorized into three sub categorization. They are very young learners, young learners, and order/late young learners. Very young learners are between the ages of about 3-6 years old; young learners are about 7-9 years old; and for older/late young learners are about 10-12 years old.

The categorizations from Harmer and Ersöz A., then are adapted as a resource where the writer reflects the ESOL (English for Speakers of Other Languages) teaching environment and the learners of English in the primary education in Indonesia. In the ages of 3 months- 2 years, some children are put in the informal education, we call it as daycare center; while in the ages of $2 / 3$ years- $4 / 5$ years, some parents send their children to playgroup; in the ages of $4 / 5$ years- $6 / 7$ years,

Indonesia young learners start their formal education in kindergarten; and in the ages of 6/7 years-11/12 years, they begin to learn at elementary school. 


\section{Table 1. General Categorization and Classification of Indonesia Young Learners School Education}

\begin{tabular}{|c|c|c|c|}
\hline \multirow{3}{*}{$\begin{array}{l}\text { ages } \\
\begin{array}{l}\text { very young } \\
\text { learners }\end{array}\end{array}$} & & \multicolumn{2}{|l|}{ school education } \\
\hline & 3 months - 2 years & daycare center & informal \\
\hline & $2 / 3-4 / 5$ years & playgroup & education \\
\hline \multirow{2}{*}{ young learners } & $4 / 5$ - 6/7 years & kindergarten & \multirow[b]{3}{*}{ formal education } \\
\hline & $6 / 7$ - 9/10 years & $1 \mathrm{st}-3 \mathrm{rd}$ grades & \\
\hline $\begin{array}{l}\text { older /late young } \\
\text { learners }\end{array}$ & $9 / 10-12 / 13$ years & 4th -6 th grades & \\
\hline
\end{tabular}

\section{CHILDREN'S COGNITIVE DEVELOPMENT BY PIAGET}

According to Piaget, children progress through a series of four critical stages of cognitive development. Each stage is marked by shifts in how kids understand the world.

\section{The Sensorimotor Stage (0-2 years)}

The sensorimotor stage is the earliest in Piaget's theory of cognitive development. It lasts from birth to approximately age two and is centered on the infant trying to make sense of the world. In this phase, children experience the world and gain knowledge through their senses and motor movements. Children utilize skills and abilities they were born with (such as looking, sucking, grasping, and listening) to learn more about the environment.

2. The Preoperational Stage (2-7 years)

This stage begins around age two as children start to talks and last until approximately age seven. During this stage, children begin to engage in symbolic play and learn to manipulate symbols. However, Piaget noted that they do not yet understand concrete logic.

During the preoperational stage, for example, a child is able to use an object to represent something else, such as pretending a broom is a horse. Children often play the roles of "mommy", "daddy", "doctor", and many other characters. In this stage, children are unable to take on another person's perspective (egocentricism), lack the understanding that objects can change in appearance while still maintaining the same properties.

3. The Concrete Operational Stage (7-11 years)

This period spans the time of middle childhood and is characterized by the development of logical thought. While kids at this age become more logical about concrete and specific things, they still struggle with abstract ideas. During this time, children gain a better understanding of mental operations. They begin thinking logically about concrete events, but have difficulty understanding abstract or hypothetical concepts.

Piaget determined that children in the concrete operational stage were fairly good at the use of inductive logic (inductive reasoning). Inductive logic involves going from a specific experience to a general principle. For example if we are noticing that every time we are around a cat, we have itchy eyes, a runny nose, and a swollen throat. We might then reason from that experience that we are allergic to cats.

On the other hand, children at this age have difficulty using deductive logic, which involves using a general principle to determine the outcome of a specific event. 
For example, a child might learn that $\mathrm{A}=\mathrm{B}$, and $\mathrm{B}=\mathrm{C}$, but might still struggle to understand that $\mathrm{A}=\mathrm{C}$.

One of the most important developments in this stage is an understanding of reversibility, or awareness that actions can be reversed. For example, a child might be able to recognize that his or her dog is a Labrador, that a Labrador is a

dog, and that a dog is an animal. Kids at this point are aware that other people have unique perspectives, but they might not yet be able to guess exactly how or what that other person is experiencing.

4. The Formal Operational Stage (adolescence and spans into adulthood)

At this point in development, thinking becomes much more sophisticated and advanced. Kids can think about abstract and theoretical concepts and use logic to come up with creative solutions to problems.

Those stages above have to be understood well by teachers. Teachers are also required to determine what language focus and skills appropriate and relevant to them; so that the roles of teachers as facilitators can really help them to construct their understanding about the world with English.

\section{VAK LEARNING STYLES}

Knowing and understanding the children's learning styles are very needed because it refers to two related ideas: firstly that students have different preferences for how learning material is presented, and secondly that when material is presented in a way that suits a learner's preference, learning is somehow increased. The matching of learner preference with material will improve children's learning outcomes.

Generally, children have different ways of learning. Bandler and Grinder (1988) identified three characteristics of different learners:

Those who prefer a visual learning style will look at the teacher's face intently, like looking at wall displays, books etc. They will often recognize words by sight, use lists to organize their thoughts and recall information by remembering how it was set out on a page.

Those who prefer an auditory learning style like the teacher to provide verbal instruction, like dialogues, discussions and plays, solve problems by talking about them and use rhythm and sound as memory aids.

Those who prefer a kinesthetic learning style: learn best when they are involved or active, find it difficult to sit still for long periods and use movement as a memory aid.

\section{Visual Learners}

Children who have this learning style will thrive if they are given regular opportunities to present their work pictorially. For their learning to make sense they need to be able to see, visualize and illustrate their knowledge skills and concepts. Visual learning characteristics include remembering visual details, preferring to see what they are learning, needing to have paper and pens handy, doodling while listening, liking to write down instructions or see them demonstrated. Visual learners may also benefit from using mind-maps or flow-maps to explain different processes and using different colors to highlight their work. And nothing's worth to tell these learners how to do something- they need to see it. 


\section{Auditory Learners}

This type of learner will be happiest communicating their ideas verbally. They learn through listening to what others have to say and talking about what they're learning. They're also more likely to remember information by talking aloud, need to have things explained orally, may have trouble with written instructions, talk to themselves while learning something new, and enjoy discussion groups over working alone. Auditory learners may also feel more at ease expressing their ideas into a tape recorder or flip-cam.

Children who have this predominant learning style will also enjoy teaching that is linked to anecdotes/jokes.

\section{Kinesthetic Learners}

These learners like to be actively involved in the learning process, and learn best through handson activities and movement. Other kinesthetic characteristics are they want to actually do whatever is being talked about or learned, like to move around while listening or talking, often "talk" with their hands, like to touch things in order to learn about them, and remember events by recalling who did what rather than who said what.

Children with this learning style will enjoy working in groups. Kinesthetic learners can also be supported by allowing them to use models and objects to describe their ideas. Games can be utilized to support their understanding of materials. Kinesthetic learners will also enjoy reading books with strong plots. It is worth noting that these types of learners can be misdiagnosed as troublemakers because the more tradition visual or auditory learning styles just don't work for them.

\section{DISCUSSION TEACHING STRATEGIES}

After knowing the development of children and when they are categorized as very young learners, young learners, and older/late young learner, and having understood that every child has their own preference in learning, it is best time for teachers to determine and consider what strategies are required to introduce them with English.

\section{Multisensory Teaching Strategy}

The multisensory approach is a valuable tool in teaching-learning process. There are no two children who have the same way in learning. However, the students will use the combination of their senses to catch information. (McIntosh and Pack in Arrido, 2009:14) states: When children hear information, one avenue to memory is accessed. When children hear and see information, two avenues are accessed. When children hear, see and touch information, three avenues are accessed. The more avenues that we can access in a lesson are better the chance that information will lock itself in to a child's memory.

Multisensory instruction helps children tap into their learning strengths to make connections and form memories. And it allows them to use a wider range of ways to show what they've learned. Multisensory teaching takes into account that different kids learn in different ways. And it provides multiple ways to learn, it gives every children in the class a chance to succeed.

The following activities will accommodate students' learning style: 
Visual activities use:

Text or picture on a paper, posters, models, computer

Film, video, multi-image media

Color for highlighting, organizing information, or imagery Auditory activities use:

Books on tape

Film, video, multi-image media with accompanying video

Music, song, instruments, speaking, language games, etc.

Kinesthetic activities use: Small object

Modeling materials

Clapping, stomping or other movements A song relates to materials

Dancing, flashcard, and other learning games

\section{Richard's Teaching Strategy}

A number of principles below are the strategies that can be used to teach young learners in general (Richard, n.d.)

\section{Build Teaching around Activities and Physical Movement।}

Link language learning to physical activities by having children use and hear English for making things, drawing pictures, completing puzzles, labeling pictures, matching words and pictures, playing games, acting out movements in response to instructions and other activities that involve hands, eyes and ears.

Teachers often make use of TPR activities. Many listening activities for young children use this principle, such as activities in which children listen and respond to commands (e.g. 'sit down', 'turn around', 'touch your nose'), listen and choose a picture, listen and draw a picture or listen and number a sequence of actions in a picture.

Similarly, speaking activities with young learners may involve use of songs, dialogues, chants and fixed expressions that students can practice in different situations.

\section{Build Lessons around Linked Activities}

Activities of five to ten minutes in length are most successful. A balance between the following kinds of activities is often useful:

Quiet / noisy activities.

Different skills: listening, talking, reading / writing.

Individual work / pair work / group work / whole-class activities.

Teacher-pupil / pupil-pupil activities.

\section{Build Lessons around Tasks}

A task is a meaning-focused activity that requires learners to draw on and use their existing linguistic resources to complete a task, such as drawing a picture from oral instructions, or working in pairs or groups and sequencing a series of pictures to complete a story. The key features of classroom tasks for young language learners are:

They have coherence and unity for learners (from topic, activity and/or outcome).

They have meaning and purpose for learners. They have clear language-learning goals.

They involve the learner actively. 


\section{Provide Scaffolding}

Scaffolding refers to how a child learns through collaboration with a more knowledgeable partner (a parent, a classmate, a teacher). When children work collaboratively on tasks (such as sequencing pictures in a story, completing a puzzle or completing an information-gap task), more proficient learners can often provide the scaffolding less proficient learners need.

\section{Involve Students in Creating Resources that Support their Learning}

Learners can draw pictures of the characters they hear in a story or create puppets to help retell a story. They can color pictures of items and characters from stories. They can find pictures in magazines, related to a theme or topic in a lesson, and bring them to class. In Richard's Quebec primary classes mentioned earlier, they did not use a textbook. The children created their own course book, as the course developed, using the resources that formed the basis of the course.

\section{Build Lessons around Themes}

Lessons can be built around topics or themes, such as animals, friends, food or family, for very young learners; and for older learners, themes can be drawn from subjects in their other classes and the community, such as transport, country life, travel and famous people. Theme-based lessons provide continuity across activities and enable English learning to be connected to the children's lives.

\section{Choose Content Children are Familiar with}

Teaching can also be built around familiar content from the children's culture, such as stories and events (e.g. national holidays or cultural practices).

\section{Use Activities that Involve Collaboration}

Children enjoy socializing with other children, and activities that work best with young learners are those in which children are working with others in pairs or groups, rather than remaining in their seats, listening to the teacher.

\section{Create a Supportive Learning Community in the Classroom}

A class of young learners needs to become a community of learners - that is, a group of learners with shared goals, needs and concerns. Thinking of a class as a community means seeing it as a place where each child in the class cooperates and collaborates to achieve the class's common goals.

\section{Use Enjoyable Activities that Children Can Accomplish without Frustration}

Young learners enjoy taking part in activities that they can successfully achieve, but which also offer some kind of challenge. Activities of this kind depend on the teacher providing language input and modelling for young language learners, where the teacher and the materials are the primary source of language.

\section{Provide Rich Language Support}

Since the learners will have little knowledge of English to call upon, they need careful language support for learning activities. Success will depend on the teacher providing language models, demonstrating the way the activities can be carried out in English and providing the language support an activity depends upon. 


\section{Give clear goals and feedback}

Children like to be successful at things they do in class. In order to achieve this, it is important to set clear goals for children and to let them know when they have been successful, or if not, why not. Praise for success is very important for young learners, for example, by using stars, stickers, points or smiley faces.

\section{Use English for Classroom Management}

Use English for instructions, for routines such as greeting students, forming groups, for introducing activities, for giving feedback and for other teaching processes. It is good start to accustom young learners with simple words, phrases, or common expressions, such as "hello..!", "good morning...", "how are you today?", etc.

\section{Use the Mother Tongue when Needed}

It is quite appropriate to use the mother tongue when necessary to explain the meaning of words and expressions and to help explain activities. Occasional use of the mother tongue provides a comfort zone for young learners, though the teacher and students should not become over-dependent on it.

\section{Bring Speakers of English to Class}

Where possible, it is useful to invite speakers of English to class to meet the learners. These could be children from an international school or older children who are now quite advanced in English. They can ask and answer simple questions, take part in a role play and do other activities that will interest and motivate the learners.

\section{CONCLUSION AND SUGGESTION}

In this literature review paper, the writer provides a suggestion of activities, served in table 3 , in which the activities use multisensory activities and strategies from Richard. This suggestion absolutely needs adapting, modifying, and developing remembering every practice in any classroom has different goals to achieve.

The writer took an example of the material from the syllabus of the first grade of elementary school (exception: bilingual, dyslexia, Islamic school) semester one of competency-based curriculum: 1) adapt the learning goals found in the syllabus; 2) put the activities of multisensory; and 3) implement most of the strategies suggested by Richard across activities.

Richard (n.d) noted that the key features of classroom tasks for young language learners are:

They have coherence and unity for learners (from topic, activity and/or outcome).

They have meaning and purpose for learners.

They have clear language-learning goals.

They involve the learner actively.

While the multisensory activities are the combinations of learning styles which children have (visual, auditory, kinesthetic). 
The $2^{\text {nd }}$ TEYLIN International Conference Proceedings

April 2017

Table 3. Strategies across Activities for Young Learners

\begin{tabular}{|c|c|c|c|c|}
\hline $\begin{array}{l}\text { Integrated } \\
\text { skills } \\
\text { (material) }\end{array}$ & learning activities & Approach & Multisensory & Learning goals \\
\hline $\begin{array}{l}\text { Listening } \\
\text { Speaking } \\
\text { (my body) }\end{array}$ & $\begin{array}{l}\text { teacher provides large } \\
\text { pictures about 'parts of } \\
\text { body' } \\
\text { brain storming } \\
\text { students look at the } \\
\text { large pictures and learn } \\
\text { students listen and } \\
\text { repeat words loudly } \\
\text { students listen then } \\
\text { act the teacher's } \\
\text { instructions about the } \\
\text { words } \\
\text { note: use a song 'head } \\
\text { shoulders knees and } \\
\text { toes' to make the } \\
\text { classroom more fun } \\
\text { read the words on the } \\
\text { pictures of the body } \\
\text { together it can be while } \\
\text { touching them (one by } \\
\text { one for checking) } \\
\text { work in pairs or } \\
\text { groups } \\
\text { write five (or more) } \\
\text { words each student } \\
\text { correctly } \\
\text { present } \\
\text { a successful group/pair }\end{array}$ & \begin{tabular}{|l} 
Audio \\
lingual \\
method \\
- drilling \\
Total \\
Physical \\
response \\
\\
Cooperative \\
Learning \\
social \\
alue) \\
\\
\end{tabular} & $\begin{array}{l}\text { Visual } \\
\text { Auditory } \\
\text { Auditory \& } \\
\text { kinesthetic }\end{array}$ & $\begin{array}{l}\text { respond by } \\
\text { repeating w } \\
\text { respond by } \\
\text { repeating w } \\
\text { respond and } \\
\text { model (or } \\
\text { spell the words } \\
\text { well } \\
\text { read the words } \\
\text { with goo } \\
\text { read the words } \\
\text { well and } \\
\text { write the words } \\
\text { correctly }\end{array}$ \\
\hline & $\begin{array}{l}\text { will be rewarded } \\
\text { teacher gives feedback }\end{array}$ & & & \\
\hline
\end{tabular}


It is good to say that English teachers should understand 'whom they teach', their cognitive development, and their learning styles in receiving knowledge in the form of language; so that, the children will obviously get great outcomes in the form of their achievement. And teachers have also great result from the effect of their teaching in the form of self-satisfaction, higher demands, and successful performance which become their modal to get their professionalism.

When teachers are teaching young learners or children in global, they have to be careful to select relevant and appropriate materials in accordance with their cognitive development. Teachers of English have to be allowed to create their own curriculum which suits to the need of their students in the classroom. Teachers have also to consider and be able to determine what meaningful activities they are going to provide to enhance their students' involvement in learning English, in view that they have different learning styles. After that, the purposeful strategies are made to achieve the goals of learning.

\section{REFERENCES}

Ersöz, A. (2007). Teaching English To Young Learners. Ankara: EDM Publishing. H armer, J. (2007). How to Teach English. Harlow: Pearson Education Limited. Harmer, J. (2007). The Practice of English language teaching (4th Ed.). Essex: Pearson Longman.

Piaget, J. (1977). Gruber, H.E.; Voneche, J.J. eds. The essential Piaget. New York: Basic Books.

Piaget, J. (1983). Piaget's theory. In P. Mussen (ed). Handbook of Child

Psychology. $4^{\text {th }}$ edition. Vol. 1. New York: Wiley. http://www.professorjackrichards. $\mathrm{com} /$ category/question/ 